\title{
Comparative susceptibility of Anticarsia gemmatalis Hübner (Lepidoptera: Erebidae) and Chrysodeixis includens (Walker) (Lepidoptera: Noctuidae) to insecticides
}

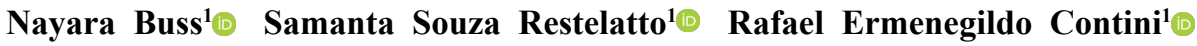 \\ Adeney de Freitas Bueno ${ }^{2}$ Oderlei Bernardi ${ }^{3}$ \\ Mari Inês Carissimi Boff ${ }^{1}$ Cláudio Roberto Franco ${ }^{1^{*}}$ (B)
}

${ }^{1}$ Programa de Pós-graduação em Produção Vegetal, Centro de Ciências Agroveterinárias (CAV), Universidade do Estado de Santa Catarina (UDESC), 88520-000, Lages, SC, Brasil. E-mail: claudio.franco@udesc.br. "Corresponding author.

${ }^{2}$ Empresa Brasileira de Pesquisa Agropecuária (EMBRAPA Soja), Londrina, PR, Brasil.

${ }^{3}$ Departamento de Defesa Fitossanitária, Centro de Ciências Rurais (CCR), Universidade Federal de Santa Maria (UFSM), Santa Maria, RS, Brasil.

ABSTRACT: Chrysodeixis includens (Walker) and Anticarsia gemmatalis Hübner are important soybean defoliators. The chemical control of A. gemmatalis has been easier and more effective than that of C. includens. It is hypothesized that $C$. includens is natural tolerant to insecticides. This study quantified and compare the susceptibility of $C$. includens and A. gemmatalis to the insecticides flubendiamide, methomyl, and spinetoram. A susceptible population of each species, maintained under laboratory conditions without insecticides selection pressure for more than 17 generations, was used. Ingestion bioassays using five to eight concentrations of each insecticide applied on the artificial diet surface were used to estimate the $L C_{50}$ and $L C_{99}\left(L C=\right.$ Lethal Concentration). The tolerance ratio (TR) was calculated by dividing the $L C_{50}$ or $L C_{99}$ of the most tolerant species by the respective value of the most susceptible species. Chrysodeixis includens was more tolerant to all insecticides tested than A. gemmatalis, with TR ${ }_{50}$ values of 45.9-, 10.0- and 2.6-fold for methomyl, flubendiamide, and spinetoram. These findings indicated that the risk of evolution of resistance may be higher for $C$. includens than A. gemmatalis due to differential survival when exposed to the same dose of insecticide applied in soybean fields. Therefore, to improve the control of both species, integrated pest management (IPM) and insect resistance management (IRM) strategies should be considered to avoid control failures in field conditions.

Key words: Glycine max, chemical control, integrated pest management, insect resistance management.

Suscetibilidade comparativa de Anticarsia gemmatalis Hübner (Lepidoptera: Erebidae) e Chrysodeixis includens (Walker) (Lepidoptera: Noctuidae) a inseticidas

RESUMO: Chrysodeixis includens (Walker) e Anticarsia gemmatalis Hübner são importantes desfolhadoras da cultura da soja. O controle químico de A. gemmatalis tem sido mais fácil e eficaz quando comparado a C. includens, sendo uma hipótese para isso a maior tolerância natural de C. includens aos inseticidas. Nesse sentido, o objetivo deste estudo foi quantificar e comparar a suscetibilidade de C. includens $e$ A. gemmatalis aos inseticidas fubendiamida, metomil e espinetoram. Nos bioensaios foram utilizadas uma população suscetivel de referência de cada espécie, mantidas em laboratório sem pressão de seleção por inseticidas a mais de 17 gerações. O método de bioensaio foi o de ingestão com aplicação de cinco a oito concentrações de cada inseticida na superfície da dieta artificial para estimativa da $C L_{50}$ e $C L_{99}(C L=$ Concentrações Letais). A razão de tolerância (RT) foi calculada pela divisão da $C L_{50}$ ou $C L_{99}$ da espécie mais tolerante pelo respectivo valor da espécie mais suscetivel. Chrysodeixis includens foi mais tolerante aos inseticidas testados do que A. gemmatalis. A tolerância diferencial pode indicar o risco de evolução da resistencia, nesse caso maior para $C$. includens a metomil e flubendiamida, porque apresentaram maiores valores de $R T_{50}\left(45,9\right.$ e 10,0 vezes respectivamente) do que para espinetoram ( $R T_{50} 2,6$ vezes). Para evitar fracassos no controle é importante adotar as premissas do Manejo Integrado de Pragas (MIP) e do Manejo da Resistência de Insetos (MRI).

Palavras-chave: Glycine max, controle químico, Manejo Integrado de Pragas, Manejo da Resistência de Insetos.

\section{INTRODUCTION}

Insect pests are an important biotic factor that reduces soybean [Glycine max L. (Merr.)] yield (OLIVEIRA et al., 2014; SILVA et al., 2020). Velvetbean caterpillar, Anticarsia gemmatalis Hübner, 1818 (Lepidoptera: Erebidae), and soybean looper, Chrysodeixis includens (Walker, [1858]) (Lepidoptera: Noctuidae), are the two main soybean defoliator pests in Brazil (BUENO et al., 2011; WILLE et al., 2017).

Chrysodeixis includens was considered a secondary pest in soybean until the end of the 90 s. It rarely caused damage, mainly due to natural control by entomopathogenic fungi (MORAES et al., 1991; SPECHT et al., 2015). However, population outbreaks of this species have become more frequent since the 2000s; this could be associated with a low 
incidence of natural enemies (entomopathogenic fungi) due to the increased use of fungicides (SOSAGÓMEZ et al., 2003; BALDIN et al., 2014) and the adaptation of $C$. includens populations accompanying the expansion of soybean cultivation in different Brazilian regions (SILVA et al., 2020). However, the difference in susceptibility to insecticides between lepidopteran species is also another factor that may have contributed to the high incidence of $C$. includens in soybean (MORAES et al., 1991). Chrysodeixis includens has naturally been more tolerant to insecticides than other species such as $A$. gemmatalis (ROSE et al., 1988) and Helicoverpa armigera (HÜBNER, 1808) (Lepidoptera: Noctuidae) (SCHNEIDER \& SOSA-GÓMEZ, 2016).

When exposed to a certain insecticide, the differential survival of a given species can also increase the risk of evolution of resistance (GEORGHIOU, 1983; BERNARDI et al., 2012). In Brazil, intraspecific variability in susceptibility to insecticides has been reported in $C$. includens, showing that this species can adapt to insecticides (RESTELATTO et al., 2021; STACKE et al., 2019; QUEIROZ et al., 2020). The differences in insect susceptibility to insecticides affect integrated pest management (IPM) and insect resistance management (IRM) programs. Based on this, wequantified and compared the susceptibility of $A$. gemmatalis and $C$. includens to the insecticides flubendiamide, methomyl, and spinetoram.

\section{MATERIALS AND METHODS}

\section{Rearing of A. gemmatalis and C. includens}

The susceptible reference population of A. gemmatalis (SUSAG) was obtained from Embrapa Soybean. This population was collected in the soybean crop in May 2011 in Sertanópolis, PR, Brazil. The susceptible reference population of $C$. includens (SUSCI-15) was provided by the company PROMIP LTDA, being collected in the soybean crop in December 2015 in Engenheiro Coelho, SP, Brazil. Both populations were maintained under laboratory conditions in the absence of insecticides selection pressure, as briefly described in the following.

Adult insects were placed in polyvinyl chloride tubes $(200 \mathrm{~mm} \times 200 \mathrm{~mm})$ lined with bond paper (oviposition substrate). Food was supplied using Petri dishes $(50 \mathrm{~mm})$ with cotton soaked with $10 \%$ honey solution. Eggs were removed every two days and transferred to plastic pots $(145 \mathrm{~mL})$ containing a bean-based artificial diet adapted from GREENE et al. (1976). Larvae were individualized in 50-mL plastic cups containing the artificial diet when they reached the third instar. The rearing was maintained at room temperature at $25^{\circ} \mathrm{C} \pm 2{ }^{\circ} \mathrm{C}$, relative humidity of $70 \% \pm 10 \%$, and 14 -hour photophase (PANIZZI \& PARRA, 2009).

\section{Toxicological bioassay}

Artificial diet-overlay bioassays were conducted to evaluate the effects of insecticides on C. includens and A. gemmatalis. The insecticides consisted of flubendiamide $\left(\mathrm{Belt}^{\mathbb{R}}, 480 \mathrm{~g}\right.$ a.i./L, IRAC MoA group: 28), methomyl (Lannate ${ }^{\circledR}, 215 \mathrm{~g}$ a.i./L, IRAC MoA group: 1A), and spinetoram (Exalt ${ }^{\mathbb{B}}, 120 \mathrm{~g}$ a.i./L, IRAC MoA group: 5). An aliquot of $1.2 \mathrm{~mL}$ of the artificial diet was deposited in each well of 24well acrylic plates (Costar ${ }^{\circledR}$, model 3526, Cambridge, Massachusetts, USA). Then, the insecticides were diluted using distilled water to prepare from five to eight concentrations. The surfactant Triton X-100 ${ }^{\circledR}$ (Labsynth Ltda, SP, Brazil) at $0.1 \%$ was added to each concentration. An aliquot of $30 \mu \mathrm{L}$ of the insecticide solution was applied on the diet surface of each well. After drying ( $\sim 60$ minutes), a single $A$. gemmatalis or $C$. includens larva at the beginning of the third instar was placed in each well.

A total of 96 to 144 larvae were tested for each concentration (four to six replicates of 24 larvae per concentration). Plates were maintained at room temperature at $25^{\circ} \mathrm{C} \pm 2^{\circ} \mathrm{C}$, relative humidity of $70 \% \pm 10 \%$, and 14 -hour photophase. Mortality was evaluated 96 hours after exposure to flubendiamide (OWEN et al., 2013) and 72 hours to methomyl and spinetoram (MASCARENHAS \& BOETHREL, 2000). Larvae without movement after light touch with a brush were considered dead.

\section{Data analysis}

The concentration-mortality data were submitted to Probit analysis using the SAS University Edition software version 9.4 (SAS Institute, 2020) to estimate the lethal concentrations $\left(\mathrm{LC}_{50}\right.$ and $\left.\mathrm{LC}_{99}\right)$ and respective confidence intervals $(95 \% \mathrm{CI})$. The tolerance ratio $\left(\mathrm{TR}_{50}\right.$ or $\left.\mathrm{TR}_{99}\right)$ was calculated by dividing the $\mathrm{LC}_{50}$ or $\mathrm{LC}_{99}$ of the most tolerant species by the respective value of the most susceptible species (ROBERTSON \& PREISLER, 1992).

\section{RESULTS AND DISCUSSION}

Chrysodeixis includens was more tolerant to the insecticides flubendiamide, methomyl, and spinetoram than A. gemmatalis (Table 1). This difference in susceptibility between species may be associated with the receptors at the insecticide site 
Table 1 - Concentration-mortality response (LC; $\mu \mathrm{g}$ a.i./. $\left.\mathrm{cm}^{2}\right)$ of third instar Anticarsia gemmatalis and Chrysodeixis includens larvae exposed to insecticides in diet-overlay bioassays.

\begin{tabular}{|c|c|c|c|c|c|c|c|}
\hline Species & $\mathrm{n}^{\mathrm{a}}$ & Slope $( \pm$ SE) & $\mathrm{LC}_{50}(95 \% \mathrm{FL})^{b}$ & $\mathrm{LC}_{99}(95 \% \mathrm{FL})^{a}$ & $\chi^{2^{c}}$ & $\mathrm{df}^{\mathrm{d}}$ & $\mathrm{TR}_{50}{ }^{\mathrm{e}}$ \\
\hline \multicolumn{8}{|c|}{--------------------------------------------------------------------------Flubendiamide--------------------------------------------------------------------- } \\
\hline A. gemmatalis & 912 & $1.23( \pm 0.15)$ & $0.0055(0.0026-0.0095)$ & $0.42(0.17-2.06)$ & 10.80 & 5 & - \\
\hline C. includens & 792 & $2.32( \pm 0.20)$ & $0.055(0.046-0.064)$ & $0.55(0.41-0.83)$ & 4.68 & 4 & 10.0 \\
\hline \multicolumn{8}{|c|}{ - } \\
\hline A. gemmatalis & 672 & $0.86( \pm 0.06)$ & $0.083(0.053-0.128)$ & $41.70(19.71-107.91)$ & 4.15 & 4 & - \\
\hline C. includens & 960 & $2.12( \pm 0.16)$ & $3.83(3.13-4.55)$ & $48.20(36.87-68.05)$ & 4.44 & 4 & 45.9 \\
\hline \multicolumn{8}{|c|}{ 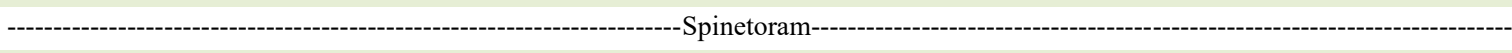 } \\
\hline A. gemmatalis & 864 & $1.19( \pm 0.11)$ & $0.0057(0.0041-0.0075)$ & $0.50(0.27-1.23)$ & 9.78 & 6 & - \\
\hline C. includens & 600 & $1.78( \pm 0.15)$ & $0.0147(0.0118-0.0179)$ & $0.30(0.19-0.53)$ & 1.24 & 3 & 2.6 \\
\hline
\end{tabular}

${ }^{\mathrm{a}}$ Numbers of larvae tested

${ }^{\mathrm{b}} \mathrm{LC}_{50}$ is the concentration of insecticide required to kill $50 \%$ of larvae. Similarly, $\mathrm{LC}_{99}$ is the concentration of insecticide required to kill $99 \%$ of larvae tested.

${ }^{\mathrm{c}}$ Chi-square values $(\mathrm{P}>0.05$ in the goodness-of-fit test)

${ }^{\mathrm{d}}$ Degrees of freedom.

${ }^{\mathrm{e}}$ Tolerance Ratio $(\mathrm{TR})=\mathrm{LC}_{50}$ of most tolerant species $/ \mathrm{LC}_{50}$ of most susceptible.

of action among insect species (QI \& CASIDA, 2013), as well as in insect enzyme inhibitors, such as mixed-function oxidase, carboxylesterase, and glutathione S-transferase, that detoxify insecticides, promoting insects survival. The importance of these enzymes also varies between species, contributing to differences in tolerance (WU et al., 2007).

The magnitude of tolerance observed between $C$. includens and $A$. gemmatalis to the tested insecticides depended on the insecticide. The $\mathrm{TR}_{50}$ was 10.0-, 45.9-, and 2.6-fold for flubendiamide, methomyl, and spinetoram, respectively (Table 1). The variation in the magnitude of tolerance of C. includens compared to $A$. gemmatalis has also been verified for other insecticides, such as methylparathion (341-fold) and permethrin (1.6-fold), but fenvalerate, acephate, and methomyl showed no significant differential susceptibility between the two species (ROSE et al., 1988).

The toxicity of an insecticide can be influenced by factors such as food quality, stage of insect development, and genetic variability between populations (ROSE et al., 1988; SMIRLE et al., 2013; BUENO et al., 2017; SILVA et al., 2020). Previous reports in the literature recorded that the variation in tolerance between $C$. includens and $H$. armigera populations to flubendiamide was from 11- to 2,464fold. This variation in tolerance was related to the origin of the populations, especially for $C$. includens, which presented a resistance ratio of up to 217fold (SCHNEIDER \& SOSA-GÓMEZ, 2016). The experiments of this study used susceptible populations maintained under laboratory conditions, with the absence of insecticides selection pressure, to avoid the influence of the presence of insecticide-resistant larvae.

The comparison between the $\mathrm{LC}_{99}$ values showed no difference in tolerance between $C$. includens and $A$. gemmatalis, with $\mathrm{TR}_{99}$ lower than 1.3-fold (Table 1 and Figure 1) suggesting that the difference in the tolerance depends on the insecticide concentration. Difficulties in pest control using insecticides due to differences in susceptibility usually occur in cases where this magnitude is higher than 10-fold (FFRENCH-CONSTANT \& ROUSH, 1990). Thus, the decrease in insecticides residue in the field may lead to $C$. includens survival. At the same time, the mortality of $A$. gemmatalis is still observed under the same conditions. This hypothesis should be more evident for flubendiamide and methomyl because they demonstrated a higher difference of tolerance $\left(\mathrm{TR}_{50}\right.$ $>10.0$-fold) than spinetoram $\left(\mathrm{TR}_{50}=2.6\right.$-fold) (Table 1 and Figure 1).

Based on the natural tolerance of $C$. includens compared to A. gemmatalis to insecticides, the importance of their correct identification in pest sampling is reinforced for the proper choice of the insecticide dose. Otherwise, this differential survival with the use of an inadequate or excessive dose of insecticides could also explain the population 


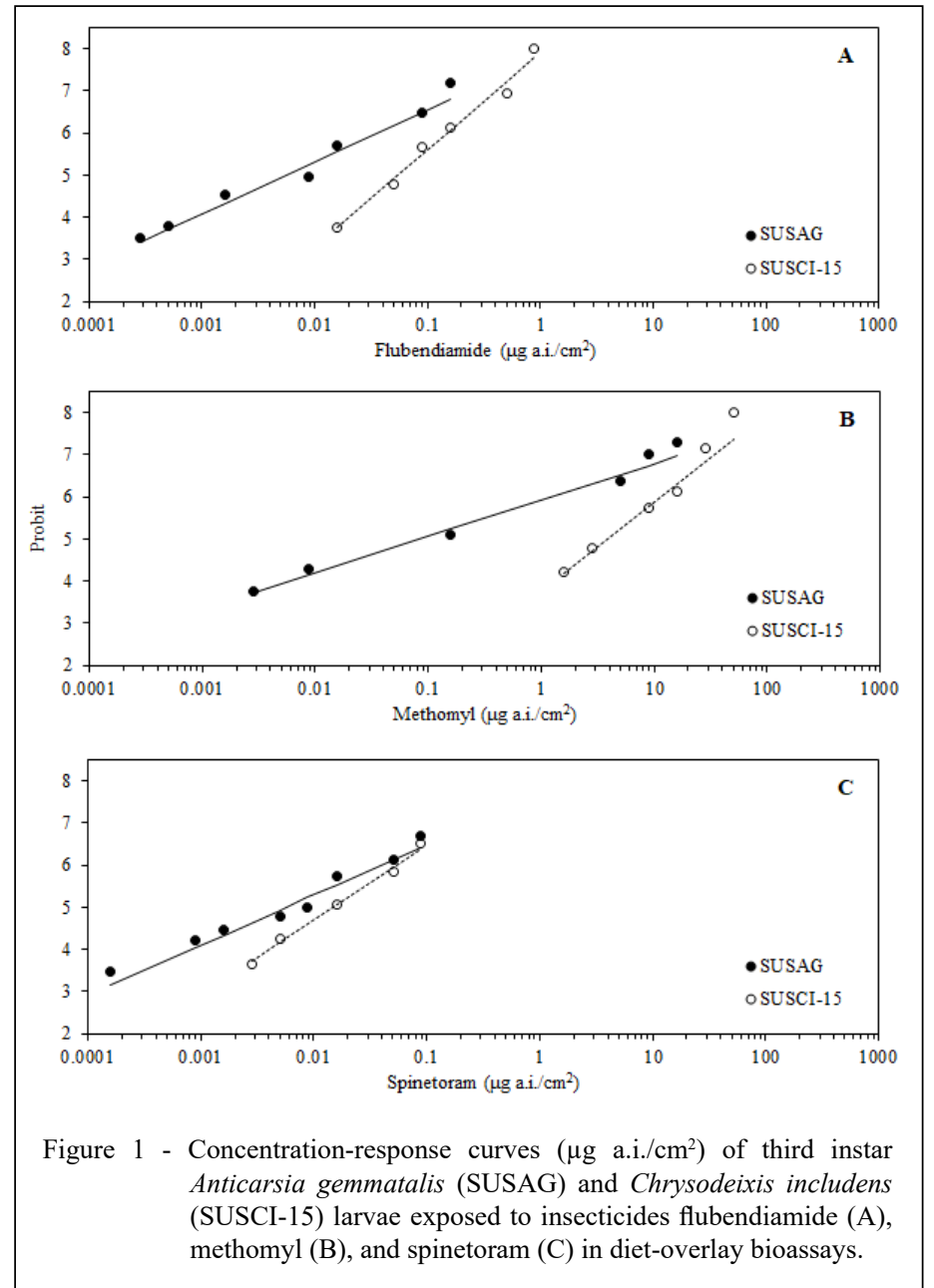

outbreaks of $C$. includens observed in recent years in the soybean crop (MORAES et al., 1991). From an IRM perspective, an adequate dose of insecticide should be sufficient to cause the mortality of heterozygous resistant insects; otherwise, it may accelerate the evolution of resistance (GEORGHIOU, 1983; BERNARDI et al., 2012). Thus, the differential tolerance of $C$. includens could favor the evolution of resistance of this species.

The use of genetically modified soybean by inserting the insecticidal protein CrylAc from Bacillus thuringiensis Berliner, 1915 is another important method of controlling $C$. includens and A. gemmatalis (BUENO et al., 2020). The natural tolerance of $C$. includens to this insecticidal protein is also identified as a risk factor for accelerating the evolution of resistance (BERNARDI et al., 2012; YANO et al., 2015).
Resistant $A$. gemmatalis populations were detected between 1987 and 1991 in the USA and Brazil for Baculovirus anticarsia (ABOT et al., 1996; MOTA-SANCHEZ \& WISE, 2020). Moreover, resistant $C$. includens populations have been documented since the ' $70 \mathrm{~s}$ in the USA for various insecticides, such as chlorinated, phosphorous, carbamates, and pyrethroids (MASCARENHAS \& BOETHREL, 2000). In Brazil, this record has been recent, but populations with a resistance ratio higher than 10-fold have already been detected for flubendiamide, chlorantraniliprole, methomyl, lambda-cyhalothrin, methoxyfenozide, novaluron, teflubenzuron, and spinosad (RESTELATTO et al., 2021; STACKE et al., 2019; QUEIROZ et al., 2020). In addition, Spinetoram showed low variations in susceptibility from 2.5- to 8.6-fold (STACKE et al., 2019). This low variation in susceptibility 
corroborates the hypothesis of a low risk of evolution of resistance for this active ingredient.

Thus, differential tolerance is essential to preserve the effectiveness of synthetic insecticides and $B$. thuringiensis proteins expressed in soybean for the management of $C$. includens and A. gemmatalis. The risk of evolution of resistance can be evaluated and changes in the frequency of resistant insects monitored (BERNARDI et al., 2012; YANO et al., 2015; STACKE et al., 2019).

Adopting IPM premises is important to delay the evolution of resistance, using adequate sampling for decision-making, rotation of insecticides with different mechanisms of action, and other control methods to reduce selection pressure. These recommendations are mainly important in the $C$. includens management in refuge areas (soybean cultivation without the expression of the insecticidal protein Cry1Ac) and other crops since this is a polyphagous species and has a high gene flow between populations and crops (SPECHT et al., 2015; BUENO et al., 2020; SILVA et al., 2020).

\section{CONCLUSION}

Chrysodeixis includens is more tolerant to the insecticides flubendiamide (10.0-fold), methomyl (45.9fold), and spinetoram (2.6-fold) than A. gemmatalis.

\section{ACKNOWLEDGEMENTS}

N.B., S.S.R., and R.E.C. thank the Coordination for the Improvement of Higher Education Personnel (CAPES, Brazil), the National Council for Scientific and Technological Development (CNPq, Brazil), and the Programa de Bolsas Universitárias de Santa Catarina by the Fundo de Apoio à Manutenção e ao Desenvolvimento da Educação Superior (UNIEDU/FUMDES) for granting the scholarships. We are also grateful for the financial resources received from the Research and Innovation Support Foundation of Santa Catarina State (FAPESC) (granting No. 2017 TR653 - FAPESC/PAP/UDESC) and the Brazilian Insecticide Resistance Action Committee (IRAC-BR) (granting No. FIEPE/ CAV 001/2017).

\section{DECLARATION OF CONFLICT OF INTEREST}

The authors declare no conflict of interest. The founding sponsors had no role in the design of the study; in the collection, analyses, or interpretation of data; in the writing of the manuscript, and in the decision to publish the results.

\section{AUTHORS' CONTRIBUTIONS}

The authors N.B., S.S.R., and R.E.C. contributed to the execution of experiments and writing and revising the manuscript. A.F.B. and O.B. contributed to the conception and revision of the manuscript. M.I.C.B. contributed to the co-orientation and revision of the manuscript. C.R.F. contributed to the conception, writing, revision of the manuscript, and guidance of the master's students. All authors approved the final version of the manuscript.

\section{REFERENCES}

ABOT, A. R. et al. Development of resistance by Anticarsia gemmatalis from Brazil and the United States to a nuclear polyhedrosis virus under laboratory selection pressure. Biological Control, v.7, n.1, p.126-130, 1996. Available from: $<$ https://wwwsciencedirect.ez74.periodicos.capes.gov.br/science/article/pii/ S1049964496900754>. Accessed: Jun. 06, 2020. doi: 10.1006/ bcon. 1996.0075 .

BALDIN, E. L. L. et al. Outbreaks of Chrysodeixis includens (Walker) (Lepidoptera: Noctuidae) in common bean and castor bean in São Paulo State, Brazil. Bragantia, v.73, n.4, p.458-461, 2014. Available from: <https://www.scielo.br/pdf/brag/v73n4/ aop_brag_277.pdf > . Accessed: May, 18, 2020. doi: 10.1590/1678$4499.027 \overline{7}$.

BERNARDI, O. et al. Assessment of the high-dose concept and level of control provided by MON $87701 \times$ MON 89788 soybean against Anticarsia gemmatalis and Pseudoplusia includens (Lepidoptera: Noctuidae) in Brazil. Pest Management Science, v.68, n.7, p.10831091, 2012. Available from: <https://doi.org/10.1002/ps.3271>. Accessed: Jun. 06, 2020. doi: 10.1002/ps.3271

BUENO, A. F. et al. Challenges for adoption of Integrated Pest Management (IPM): the soybean example. Neotropical Entomology, 2020. Available from: <https://doi.org/10.1007/ s13744-020-00792-9>. Accessed: Aug. 19, 2020. Epub 31-Jul2020. doi: 10.1007/s13744-020-00792-9 (Electronic Publication).

BUENO, A. F. et al. Pesticide selectivity to natural enemies: challenges and constraints for research and field recommendation. Ciência Rural, v.47, n.6, e20160829, 2017. Available from: $<$ https://www.scielo.br/pdf/cr/v47n6/1678-4596-cr-4706-e20160829.pdf>. Accessed: Jun. 06, 2020. Epub 22-Mai-2017. doi: $10.1590 / 0103-8478 \mathrm{cr} 20160829$.

BUENO, R. C. O. F. et al. Lepidopteran larva consumption of soybean foliage: basis for developing multiple-species economic thresholds for pest management decisions. Pest Management Science, v.67, n.2, p.170-174, 2011. Available from: <https://doi.org/10.1002/ps.2047>. Accessed: Jun 06, 2020. doi: 10.1002/ps.2047.

FFRENCH-CONSTANT, R. H.; ROUSH, R. T. Resistance detection and documentation: The relative roles of pesticidal and biochemical assays. In: ROUSH, R.T.; TABASHNIK, B.E. Pesticide Resistance in Arthropods. New York: Chapman \& Hall, 1990. Cap.2, p.4-38.

GEORGHIOU, G. P. Management of resistance in arthropods. In: GEORGHIOU, G.P.; SAITO, T. Pest Resistance to pesticides. New York: Plenum Press, 1983. p.769-792.

GREENE, G. L. et al. Velvetbean caterpillar: a rearing procedure and artificial medium. Journal of Economic Entomology, v.69, n.4, p.487-488, 1976. Available from: <https://doi.org/10.1093/ jee/69.4.487>. Accessed: Dec. 18, 2020. doi: 10.1093/jee/69.4.487.

MASCARENHAS, R. N.; BOETHEL, D. J. Development of diagnostic concentrations for insecticide resistance monitoring in 
soybean looper (Lepidoptera: Noctuidae) larvae using an artificial diet overlay bioassay. Journal of Economic Entomology, v.93, n.3, p.897-904, 2000. Available from: <https://doi.org/10.1093/ jee/93.3.897>. Accessed: Jun. 06, 2020. doi: 10.1093/jee/93.3.897.

MORAES, R. R. et al. Flutuação populacional de Plusiinae e Anticarsia gemmatalis Hübner, 1818 (Lepidoptera: Noctuidae) em soja no Rio Grande do Sul. Pesquisa Agropecuária Brasileira, v.26, n.1, p.51-56, 1991. Available from: $<$ https://seer.sct.embrapa. br/index.php/pab/article/view/3161/588>. Accessed: Jun. 06, 2020.

MOTA-SANCHEZ, D.; WISE, J. C. The Arthropod Pesticide Resistance Database. Michigan State University. Online. Available from: <http://www.pesticideresistance.org $>$. Accessed: May, 05, 2020

OLIVEIRA, C. M. et al. Crop losses and the economic impact of insect pests on Brazilian agriculture. Crop Protection, v.56, n.1, p.50-54, 2014. Available from: <https://doi.org/10.1016/j. cropro.2013.10.022>. Accessed: Jun. 06, 2020. doi: 10.1016/j. cropro.2013.10.022.

OWEN, L. N. et al. Susceptibility of Chrysodeixis includens (Lepidoptera : Noctuidae) to reduced-risk insecticides. Florida Entomologist, v.96, n.2, p.554-559, 2013. Available from: $<$ https://doi.org/10.1653/024.096.0221>. Accessed: Jun. 06, 2020. doi: 10.1653/024.096.0221

PANIZZI, A. R.; PARRA, J. R. P. Bioecologia e nutrição de insetos: bases para o manejo integrado de pragas. Brasília: Embrapa Informação Tecnológica, 2009. 1.164p.

QI S.; CASIDA J. E. Species differences in chlorantraniliprole and flubendiamide insecticide binding sites in the ryanodine receptor. Pesticide Biochemistry Physiology, v.107, n.3, p. 321-326, 2013 Available from: <https://doi.org/10.1016/j.pestbp.2013.09.004>. Accessed: Jun. 06, 2020. doi: 10.1016/j.pestbp.2013.09.004.

QUEIROZ, L. F et al. Susceptibility of soybean looper to lufenuron and spinosad. Arquivos do Instituto Biológico, v.87, 1-8, e0062019, 2020. Available from: <https://doi.org/10.1590/18081657000062019>. Accessed: Jun. 23, 2020. doi: 10.1590/18081657000062019 .

RESTELATTO, S. S. et al. Intraspecific variation in the Chrysodeixis includes (Walker) (Lepidoptera: Noctuidae) susceptibility to insecticides. Pesquisa Agropecuária Tropical, v.51, n.6, e67353, 2021. Available from: <https://www.revistas. ufg.br/pat/article/view/67353>. Accessed: Nov. 06, 2021. Epub 23-Set-2021.

ROBERTSON, J. L.; PREISLER, H. K. Pesticide bioassays with arthropods. London: CRC Press, 1992. 127p.

ROSE, R.L. et al. Insecticide toxicity to the Soybean Looper and the Velvetbean Caterpillar (Lepidoptera: Noctuidae) as influenced by feeding on resistant soybean (PI 227687) leaves and coumestrol. Journal of Economic Entomology, v.81, n.5, p.1288-1294, 1988. Available from: <https://doi.org/10.1093/jee/81.5.1288>. Accessed: Apr. 19, 2020. doi: 10.1093/jee/81.5.1288.
SCHNEIDER, J. A.; SOSA-GÓMEZ, D. R. Suscetibilidade de populações de Chrysodeixis includens e Helicoverpa armigera a inseticidas do grupo das diamidas. In: Reunião de Pesquisa de Soja, 35., 2016, Londrina, PR. Resumos... Londrina: Embrapa Soja, 2016. p.64-66. Available from: <https://www.embrapa.br/ en/busca-de-publicacoes/-/publicacao/1052074/suscetibilidadede-populacoes-de-chrysodexis-includens-e-helicoverpaarmigera-a-inseticidas-do-grupo-das-diamidas $>$. Accessed: Aug. $28,2021$.

SILVA, C. S. et al. Population expansion and genomic adaptation to agricultural environments of the soybean looper, Chrysodeixis includens. Evolutionary Applications, v.13, p.2071-2085, 2020. Available from: <https://doi.org/10.1111/eva.12966>. Accessed: Jun. 15, 2020. doi: 10.1111/eva.12966.

SMIRLE, M. J. et al. Insecticide susceptibility of three species of cutworm (Lepidoptera: Noctuidae) pests of grapes. Journal of Economic Entomology, v.106, n.5, p.2135-2140, 2013. Available from: <https://doi.org/10.1603/EC13110>. Accessed: Jun. 06, 2020. doi: 10.1603/EC13110.

SOSA-GÓMEZ, D. R. et al. The impact of fungicides on Nomuraea rileyi (Farlow) Samson epizootics and on populations of Anticarsia gemmatalis Hübner (Lepidoptera: Noctuidae), on soybean. Neotropical Entomology, v.32, n.2, p.287-291, 2003. Available from: $\quad<$ http://www.scielo.br/scielo.php?script $=$ sci_ arttext\&pid $=$ S1519-566X2003000200014 $>$. Accessed: Apr. 19, 2020. doi: 10.1590/S1519-566X2003000200014.

SPECHT, A. et al. Host plants of Chrysodeixis includens (Walker) (Lepidoptera, Noctuidae, Plusiinae). Revista Brasileira de Entomologia, v.59, n.4, p.343-345, 2015. Available from: $<$ https:// www.scielo.br/pdf/rbent/v59n4/0085-5626-rbent-59-04-0343. pdf>. Accessed: Jun. 06, 2020. doi: 10.1016/j.rbe.2015.09.002.

STACKE, R. F. et al. Susceptibility of brazilian populations of Chrysodeixis includens (Lepidoptera: Noctuidae) to selected insecticides. Journal of Economic Entomology, v.112, n.3, p.1378-1387, jun. 2019. Available from: <https://doi.org/10.1093/ jee/toz031>. Accessed: Apr. 19, 2020. doi: 10.1093/jee/toz031.

WILLE, P. E. et al. Natural resistance of soybean cultivars to the soybean looper larva Chrysodeixis includens (Lepidoptera: Noctuidae). Pesquisa Agropecuária Brasileira, v.52, n.1, p.18-25, 2017. Available from: <https://www.scielo.br/pdf/pab/ v52n1/1678-3921-pab-52-01-00018.pdf>. Accessed: Mai. 18, 2020. doi: 10.1590/s0100-204x2017000100003.

WU, G. et al. Insecticide toxicity and synergism by enzyme inhibitors in 18 species of pest insect and natural enemies in crucifer vegetable crops. Pest Management Science, v.63, n.5, p.500-510, 2007. Available from: <https://doi.org/10.1002/ ps.1361>. Accessed: Jun. 06, 2020. doi: 10.1002/ps.1361.

YANO, S. A. C. et al. High susceptibility and low resistance allele frequency of Chrysodeixis includens (Lepidoptera: Noctuidae) field populations to Cry1 Ac in Brazil. Pest Management Science, v.72, n. 8, p.1578-1584, 2015. Available from: <https://doi.org/10.1002/ ps.4191>. Accessed: Jun. 06, 2020. doi: 10.1002/ps.4191 